\title{
An ARDL Approach in Food and Beverages Industry Growth Process in Malaysia
}

\author{
Rohana Kamaruddin \\ Department of Economics, Faculty of Business Management, Universiti Teknologi Mara, Malaysia \\ Tel: 60-3-5544-4935 E-mail: rohana070@salam.uitm.edu.my / rohana77@hotmail.com
}

Kamaruzaman Jusoff (Corresponding author)

Faculty of Forestry, Universiti Putra Malaysia, 43400 Serdang, Selangor. Malaysia.

Tel: 60-3-8946-7176 E-mail: kjusoff@yahoo.com

The research is financed by Universiti Teknologi MARA (Sponsoring information)

\begin{abstract}
The study examines the process of growth in the value added of food and beverages industry in Malaysia. The per capita income, population, skill and export are likely to exhibit long run relationship with the value added growth of this industry. Using the newly developed autoregressive distributed lag (ARDL) by Pesaran et al, (1995,1997, 1999 and 2000), a long run steady state equilibrium relationship between the independent variables and the growth performances of food industries is detected. Specifically this study has shown that in addition to the size of the population and percapita income, export are closely related to the growth of the value added of food and beverages industry. This empirical result would help Malaysia aspiration of becoming a hub for the halal food industry a reality.
\end{abstract}

Keywords: Value added, Error correction model, Halal food, Food and beverages, Growth

\section{Introduction}

The manufacturing sector is the fastest growing sector and the dominant force in Malaysia's growth experience. The structural transformation in the Malaysian economy has turned the country from an exporter of primary commodities into an exporter of high value added manufactured products. During the early process of development in the Malaysian economy, there occurred a dramatic decline of the proportion of GDP generated by the primary sector. It was counterbalanced by a dramatic increase in the share of industrial sector and by a modest increase in the share of the service sector. The agriculture sector's share in GDP declined from 22.3 percent in 1980 to 8.7 percent in 2002, the contribution of the industrial sector grew from 38.5 percent in 1980 to 44.5 percent in 2002 (Table 1). Based on the theory of structural change by Fisher and Clark (1957), Malaysia was categorized as a middle-income country concerned with industrial production through manufacturing.

<Table 1: Malaysia GDP By Kind of Economic Activity at 1978 Constant Prices, 1980 - 2002>

Unfortunately, even though the Malaysian manufacturing sector had experienced rapid export demand, this surge in demand had not been uniform across all industries. The rapid export growth from a set of industries did not imply that these industries were also displaying high demand growth in world markets. The annual growth of the manufacturing industry did not perform as well as its share to GDP. During the 1982 to 2002, the annual growth of manufacturing sector decreased sharply (Table 2). This condition was reflected in the Malaysian phase of industrialization, where the government policy towards industrialization kept changing over a period of three decades. The policy of the 1960s was the import substitution policy, followed by the export orientation in the 1970s, and in the 1980s it shifted back to import substitution policy. This indicated that growth in some industries and stagnation or decline in the manufacturing sector was not well balanced in terms of its contribution to the overall economy.

<Table 2 : Indicator of Manufacturing Performance: 1982 - 2002>

The food and beverages industry are one of the most important sector in the manufacturing industry. Under the Malaysian Standard Industrial Classification (MSIC) 2000, the food and beverages industry are classified under Division 15, and in the year 2000 these sector which constitute of sector 151, sector 152, sector 153, sector 154 and 
sector 155 valued at RM8,142,057 Million. Detail information regarding the classification is given in the Table 3 and the detail description of item under halal category is in Appendix 1.

\section{<Table 3: Definition of each sector under food and beverages>}

Manufacturing is defined as the mechanical of chemical transformation of inorganic or organic substance into new products whether the work is performed by power driven machines or by hand, whether it is done by the factory or in the workers home, and whether the products are sold at the wholesale or retail. (Department of Statistic,2000). Halal foods according to Malaysia External Trade Development Corporation means that all the ingredients used in manufacturing the products are approved Islamically. Where meat products are concerned, the halal certification is awarded when the producer has strictly followed procedures for slaughtering, processing and other related operations as prescribed by Islam.

Much have been said about making Malaysia a hub for halal food but has the country become one yet? Prime Minister Datuk Seri Abdullah Ahmad Badawi in launching the MIHAS (International Malaysia Halal Showcase) 2004 in his speech said that the goal of establishing Malaysia as global halal hub has been the aim of the Malaysian government for several years. According to MITI (Ministry of International Trade and Industry), at present there are no comprehensive figures on the performance of halal food production in Malaysia but the size of the market can be seen by looking at the import and export of processed food. The potential market for halal food is estimated in the range of RM1.3 trillion to RM1.5 trillion per year based on the world Muslim population of about 1.8 billion. In Malaysia itself with $60 \%$ of population being Muslim and if we estimate the per capita expenditure on food as RM1 a day, then the demand for halal product is more than RM5 billion a year.The demand for halal food is expected to expand progressively in view of the increasing trend among Muslims to observe dietary obligations. Under the Third Industrial Master Plan (2005-2010), is to position Malaysia as an international halal food hub and several potential sectors in food processing are identified.

Hence, in this study, the first issue is to examine the process of growth of food and beverages value added in Malaysia. It is hoped that the independent variables that show stable long run co-movement with the value added of food and beverages industry, will be helpful in the planning and monitoring the performance of this industry. It is also important to investigate any regularity that underlies the food and beverages sector during the industrialization process. In reviewing the related scenario, this study examines the growth process of food and beverages industry in Malaysia. To accomplish our tasks, the study adopts the newly proposed autoregressive distributed lag (ARDL). The rest of the paper is organized as follows. The next two sections discuss the definition of variables and methodology of this study. This is followed by interpretation of result. The final section concludes the paper.

\section{Definition of food and beverages industry variables}

In the study of relative growth of manufacturing industries formulated by Chenery-Taylor (1968), from the basic equation, the dependent variable is value added, and the independent variable is per capita income. However this study extended the model by making some modifications in order to capture the Malaysian economic conditions, by adding few important variables such as population, skill and export.

1) Gross value added $\left(V_{i}\right)$

The value of output less the value of intermediate consumption; it is a measure of the contribution to GDP made by an individual producer, industry or sector. The measurement is in thousand Ringgit Malaysia. The suitable value will be in nominal form. The value added rather than gross output is used since value added appears to be more appropriate measure of the importance of a sector in the economy. Tamamura (2002) used value added as one of the variables to replace GDP in his study of structural change in the Asia Pacific region.

2) Per capita income (Y)

Per capita income is an average income of a country population, it is measured by dividing the nominal GDP by the population, and the value is in the nominal form. Since per capita income is influenced by price level, it is required to change the per capita income to constant price and the value is in million Ringgit Malaysia.

\section{3) Population $(\mathrm{N})$}

Data for years 1970 - 1990 were compiled from Revised Intercensal Mid-year Population Estimates. The population estimates for 1991 - 2000 are based on the 1991 Population Census data which had earlier been adjusted for under-enumeration and to mid-year and subsequently projected to currents years. These projections are derived based on assumption of components of fertility, mortality and migration. The measurement is in thousand.

\section{4) Export of goods $(X)$}

It consists of exports of the following items from residents to non-residents, generally with a change of ownership involved: general merchandise, goods for processing, repairs of goods, goods procured in foreign ports by domestic 
carriers and non-monetary gold. The measurement is in thousand Ringgit Malaysia and in the nominal form. Exports have become a very important indicator in Malaysia's economy especially since the 1980s.

5) Skill intensities (S)

Skill intensities in this study representing technical workers and skilled workers. Technical workers are those with technical knowledge with diploma and certificates, while skilled workers are those with formal training that is required by the firm. In other words, firms have given enough training to their workers in terms of production and handling equipment. Measurement that will be used is number of technical and skilled workers (citizen and non-citizen) for that particular year. Gera and Mang (1997), in their study of Canada industrial output concluded that industries with higher skill requirements have consistently accounted for a larger proportion of total manufacturing output than their more moderately skilled counterparts.

Thus we can formulate a relationship between value added and the independent variables as follows:

\section{Methodology}

$$
\ln V_{i}=a+b_{1} \ln Y+b_{2} \ln N+b_{3} \ln X+b_{4} \ln S+e_{i}
$$

We employ the bounds testing procedure developed by Pesaran et al. 1996 (see Pesaran and Pesaran,1997; Pesaran and Shin, 1999; Pesaran et al., 2001), within an autoregressive distributed lag framework (ARDL). This procedure has several advantages over alternatives such as the Engle and Granger (1987) two-step residual-based procedure for testing the null of no cointegration and the system-based reduced rank regression approach pioneered by Johansen $(1988,1995)$ and Johansen and Juselius, 1990.

The first main advantage is that the bounds test approach can be applied regardless of the stationary properties of the variables in the sample and allows for inferences on long run estimates, which is not possible under alternative cointegration procedures. Second, the unrestricted error correction model (UECM) is likely to have better statistical properties that the two-step Engle-Grangerr method because, unlike the Engle-Granger method the UECM does not push the shot-run dynamics into the residual term (Banerjee et al., 1993,1998). The other major advantage of the bounds test approach is that it can be applied to studies that have a small sample size.

Thus, the following ARDL ( $a, b, c, d, e)$ model will be estimated:

$$
\begin{aligned}
\Delta \mathrm{V}_{\mathrm{t}}=\mu_{0}+\sum_{i=1}^{a} & \delta_{1 i} \Delta V_{t-i}+\sum_{i=0}^{b} \delta_{2 i} \Delta Y_{t-1}+\sum_{i=0}^{c} \delta_{3 i} \Delta N_{t-i}+\sum_{i=0}^{d} \delta_{4 i} \Delta S_{t-i}+\sum_{i=o}^{e} \delta_{5 i} \Delta X_{t-i} \\
& +\delta_{6} E C T_{t-1}+\varepsilon_{t}
\end{aligned}
$$

where each variable is as defined before.

The bounds test procedure involves two stages. The first stage is to establish the existence of a long run relationship. Once a long run relationship has been established, a two step procedure is used in estimating the long run relationship predicted by theory among the variables. Suppose that with respect to equation (1), theory predicts that there is a long-run relationship among $\ln \mathrm{V}_{\mathrm{i}}, \ln \mathrm{Y}_{\mathrm{t}}, \ln \mathrm{N}_{\mathrm{t}}, \ln \mathrm{X}_{\mathrm{t}}$ and $\ln \mathrm{S}_{\mathrm{t}}$. Without having any prior information about the direction of the long-run relationship among the variables, the following unrestricted error correction regressions are estimated (for Eq. (1)), taking each of the variables in turn as a dependent:

$$
\begin{array}{r}
\Delta \operatorname{lnV}_{\mathrm{t}}=\mu_{0}+\sum_{i=1}^{a} \delta_{1 i} \Delta V_{t-i}+\sum_{i=0}^{b} \delta_{2 i} \Delta Y_{t-1}+\sum_{i=0}^{c} \delta_{3 i} \Delta N_{t-i}+\sum_{i=0}^{d} \delta_{4 i} \Delta S_{t-i}+\sum_{i=o}^{e} \delta_{5 i} \Delta X_{t-i} \\
+\lambda_{i v} \ln V_{t-i}+\lambda_{2 v} \ln Y_{t-i}+\lambda_{3 v} \ln N_{t-1}+\lambda_{4 v} \ln S_{t-1}+\lambda_{5 v} \ln X_{t-1}+\varepsilon_{i t}
\end{array}
$$

When a long-run relationship exists, the F-test indicates which variable should be normalized. The null hypothesis for no cointegration among the variables in Eq. 3 is $H_{0}: \lambda_{i v}=\lambda_{2 v}=\lambda_{3 v}=\lambda_{4 v}=\lambda_{5 v}=0$, denoted by $\mathrm{F}_{\mathrm{v}}(\mathrm{V} / \mathrm{Y}, \mathrm{N}$, $\mathrm{S}, \mathrm{X})$ against the alternative $H_{0}: \lambda_{i v} \neq \lambda_{2 v} \neq \lambda_{3 v} \neq \lambda_{4 v} \neq \lambda_{5 v} \neq 0$. Similarly for the rest of the equation with different dependent variables. 
If the computed F statistics falls outside the critical bounds, a conclusive decision can be made regarding cointegration without knowing the order of integration of the regressors. For instance, if the empirical analysis shows that the estimated $\mathrm{F}_{\mathrm{v}}(\quad)$ is higher than the upper bound of the critical values then the null hypothesis of no cointegration is rejected. Once a long run relationship has been established, in the second stage, a further two step procedure is estimate the model is carried out. First the order of the lags in the ARDL model are selected using the Schwartz Bayesian Criteria (SBC) and in the second step the selected model is estimated by the ordinary least squares technique.

\section{Result and interpretation}

The first step in the analysis of this study is to check for the stationarity of all the variables (both dependent and independent variables). The unit property of the series is crucial for cointegration and causality analyses, which will be examined using the Augmented Dickey Fuller (ADF) tests. Table 4 reports the Augmented Dickey-Fuller test results in level and first difference at constant error trend.

\section{<Table 4: The Unit Root Test for Non-Stationarity>}

The results indicate that the null hypothesis of a unit root could not be rejected for all variables in levels except variable $\mathrm{X}$ (export) and V2. However, the hypothesis of unit root was rejected at the first difference for most of the variables as presented in Table 4. Since all the variables are not integrated at the same order, we proceed to test the cointegration of both dependent and independent variables by using ARDL.

We start the second step by testing the presence of long-run relationship. The bounds approach compares the calculated F-statistics against the critical value are reported in Table 5. For all the five equations the computed F-statistic that exceed the upper critical value at 1 percent and 10 percent, indicating that there is a unique cointegration relationship among the value added of food industry, per-capita income, population, export and skill.

\section{$<$ Table 5:Test for Cointegration Relationship>}

Before going to the detailed explanation of the ARDL results, Table 6 presents the diagnostic tests of each equation. The ARDL coefficients integrate the short-run dynamics in the long-run relationship of the variables. Given that the regressors are cast in the first difference, the empirical results indicate a satisfactory statistical fit, as judged by the adjusted $-\mathrm{R}^{2}$. The statistic tests for residual serial correlation do not reject the null hypothesis of no serial correlation in the residuals at 5 percent level for 2 out of 5 dependent variables. According to the J-B and Arch tests, heteroscedasticity does not pose any problem in any of the relationships at $10 \%$ level for 5 dependent variables. The test statistics also do not reject the hypothesis that the estimated equations possess a normal distribution.

\section{<Table 6: Diagnostic Testing for ECM model>}

\subsection{Long Run Relationship}

The primary focus of this study is to examine the long run effects of Y(per capita income), $\mathrm{N}$ (population), $\mathrm{X}$ (export) and $\mathrm{S}$ (skill) on the value added of food and beverages industry. The estimated long run coefficients of the relative growth of manufacturing industries model are presented in Table 7.

\section{<Table 7: Estimated Long Run Coefficients using the ARDL Approach>}

The ARDL long run coefficients results for sector 151 (V1) have the expected positive signs and are significant except export. The long run impact of per capita income, population and skill on value added for this sector differ in magnitudes, with the greatest coming from population (10.5645), followed by per-capita income (4.2863) and skill (2.6084). The coefficient of export though positive has no significant impact on value added in this sector.

In the case of sector 152 (V2), the sign of the long run coefficients is mix. The coefficients of per-capita income(0.5067), population(2.0033), and skill(0.1814) are negative sign and export (1.1322) positive but are not significant. So, we can conclude that the empirical results suggest that there is no significant impact of per capita income, population, export and skill on relative growth of value added of sector 152 (manufacture of dairy product).

For sector 153 (V3), the long run ARDL results show that all the variables have either positive or negative signs and are significant. The results indicate that export (0.6657) and per-capita income (0.5340) are the driving force in the growth of grain mill product, starches and starch products. However, the population $(-0.5418)$ and skill $(-0.2344)$ tend to decrease the growth of this sector. In the case of sector 154 (V4), the results showed that there is no long run relationship between value added in manufacture of bakery product and its determinants.

Finally, sector 155 (V5), the result showed that there is a long run cointegration relationship between dependent and independent variables. The population of (12.7825) is the major factor that enhances the relative growth of beverages industry. Per-capita income (0.6564) and export (1.9030) are also important variables that strongly contribute to the growth of this sector, skill (4.2032) has a negative effect on the value added in this sector. In general, the empirical results show that the relationship between the growth in manufacturing industries and the independent variables namely 
income, population, export, and skill are not conclusive. Indeed, the long run estimated results suggest that the effect of income, population, export, and skill could be either positive or negative.

The first equation in Table 5 indicates that value added in three sectors have positive relationship with level of income. These three sectors are sector 151 (Production, processing \& preservation of meat, fish, fruits, vegetables, oils and fat), 153 (Grain mill products, starches and starch products and prepared animal feeds) and 155 (Beverages). Moreover, the results presented in Table 4 indicate that there is a positive "size" effect between the growth of manufacturing sectors and the population variable. Among the five industry groups, only sector 155 (Beverages) is positively and statistically significant and sectors 151 (Production, processing \& preservation of meat, fish, fruits, vegetables, oils and fat), and 153 (Grain mill products, starches and starch product and prepared animal feed), have negative signs and are statistically significant.

Taking both per capita income and population coefficients together, there is a domestic "consumption effect" in the expansion of value added of sector 155 (Beverages), With regards to exports, the results show that they are positively related to value added in two sectors, namely153 (Grain mill products, starches and starch product and prepared animal feed) and 155 (Beverages). Skill intensities are positively related to value added sector of 151 (Production, processing \& preservation of meat, fish, fruits, vegetables, oils and fat).Two sectors show negative relationships to skill intensities. The two sectors are 153 (Grain mill products, starches and starch product and prepared animal feed) and 155 (Beverages).

\subsection{Error Correction Model (ECM)}

At the bottom of Table 6, we present the estimated error correction terms and short run coefficients of the food and beverages industry. The result shows that the error correction terms in all sectors, except V4, are negative and significant. The findings of the manufacturing industry of divisions 15 presented in Table 6 show that in the short run, the impact of the level of income on the growth of this manufacturing industry can be both positive or negative. The positive and significant impact of the level of income can be found in the manufacturing sector of production, processing, and preservations of meat, fish, fruits, vegetables, oils and fats (153) at lag 1. These findings are expected as the rise in the level of income is considered crucial to demand for the products from the manufacturing of sector 153. The income elasticity in the sector is moderate and ranges between -1.65 and 0.78 .

Our results could not show any impact of the level of income on in the sector 154 (Manufacture of other food products) and sector 155 (manufacture of beverages). But in sector 151 (production, processing, and preservations of meat, fish, fruits, vegetables, oils and fats) the effect of income is negative. Secondly, the results reveal that population poses positive and significant impact on the growth of food manufacturing only in sector 153 (Manufacture of grain mill products, starches and starch products and prepared animal feeds). However the effect of population is not much in the food manufacturing industry such as the manufacture of production, processing, and preservations of meat, fish, fruits, vegetables, oils and fats, the manufacture of dairy product, the manufacture of other food products and the manufacture of beverages. The impact of population on the growth of food manufacturing industry is very elastic with the elasticity range from 8.32 per cent to 25.83 per cent.

The third findings relate to the impact of the export on the growth of the food and beverages manufacturing industry. The results show that only sector 151 (production, processing, and preservations of meat, fish, fruits, vegetables, oils and fats) is affected by exports. This is largely due to the fact that Malaysia is the second largest palm oil producer and most of Malaysia 's palm oil exports are processed palm oil, which is included in the production, processing and preservations, meat, fish, fruits, vegetables, oils and fats sector. For the Manufacture of grain mill products, starches and starch products and prepared animal feeds, the impact of export is negative. Elasticity of export range from 0.6 to 1.25 percent. The fourth findings of the food manufacturing industry show that the impact of skill variable on the growth of food industry can be positive or negative. In sector 151 skill has positive effect, while in sector 152 (dairy product) it has a negative impact. The short-run elasticity of skill range from 1.47 to 1.25 . The error correction terms for all food manufacturing industry equations (ECM (-1)) prove to be significant. This provides additional support in concluding that there is co-integration. Such a finding suggests the existence of a long-term causal relationship between the variables in the model. The negative (or positive) sign of the coefficient of the error term means that it would negatively (or positively) affect the short-term growth of the dependent variable. However, the moderate elasticity coefficient of the error term indicates moderate response (i.e. speed of adjustment) of the dependent variable to the equilibrium level.

\section{Conclusion}

The main objective of this study is to examine the growth process of food and beverages industries. Results based on the ARDL analysis of manufacturing food and beverages value added shown that manufacturing output growth can be partially explained by the expansion of manufactured exports and consumption effects as indicated by positive per capita income, population and export coefficients for the majority of industrial groups. 
In the long run, the impact of per capita income is found to be positive in four equations, and significant in three out of five equations. The magnitude of the coefficients ranges from as high as 4.2863 for sector 151 to 0.5340 for sector 153 . The coefficient for population in the long run ranges as high as 12.7825 to 10.5645 for only two sectors 151 and 155 . This result provides some support for "domestic consumption effect." The impact of export on relative value added growth rate is found to be positive in four equations and significant in only two, with the range of 0.6564 to 0.6657. This implies that manufacture of grain mill products, starches and starch products and prepared animal feeds and manufacture of beverages are export oriented. In general, the study concludes that the growth of value added in food and beverages industry depends closely on per capita, population and export. This empirical result hopefully would help make Malaysian aspiration of becoming a hub for the halal food industry a reality.

\section{References}

Banerjee, A., Galbraith, J. \& Hendry, D. (1993). Cointegration, Error Correction and Econometric Analysis of Non-stationary Data. Oxford Univ.Press, Oxford.

Banerjee,A., Dolado,J. \& Mestre,R. (1998). Error-correction Mechanism Tests for Cointegration in a Single Equation Framework. Journal of Times Series Analysis 19, 267-283.

Clark, C. (1957). The Conditions of Economic Progress. $3^{\text {rd }}$ ed. Macmillan, London.

Chenery, H. B. \& Taylor, L. (1968). Developments Patterns: Among Countries and Over Time. Review of Economics an Statistics, Vol. 50. No.4, pp. $391-416$.

Fisher, A.G.B. \& Clark, C. (2001). Fisher Clark's Theory of Structural Change.http:// www. Fisher Clarks Theory Structural Change ( Biz/ed Virtual Developing Country). Accessed on 1 January 2003.

Fisher, A.G.B. \& Clark, C., (1957). Production, Primary, Secondary and Tertiary. Economic Record 15 (28), 24 - 38

Gera, S. and Mang. K. (1997). The Knowledge - Based Economy: Shifts in Industrial Output. Working Paper No. 15, Industry Canada.

Johansen,S. (1988). Statistical analysis of cointegrating vectors. Journal of Economic Dynamics and Control 12 , 231-234.

Tamamura, C. (2002). Structural Change in International Industrial Linkages and Export Competitiveness in the Asia-Pacific Region. Asean Economic Bulletin, Singapore.

Pesaran, M.H. \& B. Pesaran (1995). A Non-nested Test of Level-Differenced Versus Log - Differenced Stationary Models. Economic Reviews, 14,pp.213-27.

Table 1. Malaysia GDP By Kind of Economic Activity at 1978 Constant Prices, 1980 - 2002

\begin{tabular}{lllllll}
\hline \hline \multirow{2}{*}{ Economic Activities } & \multicolumn{7}{c}{ Percent share of GDP } \\
& 1980 & 1985 & 1990 & 1995 & 2000 & 2002 \\
\hline Agriculture & 22.3 & 20.3 & 16.3 & 10.3 & 8.9 & 8.7 \\
Mining and quarrying & 12.8 & 13.3 & 9.4 & 8.2 & 7.3 & 7.2 \\
Manufacturing & 18.5 & 18.5 & 24.6 & 27.1 & 31.9 & 29.9 \\
Electricity, gas and water & 2.2 & 2.5 & 2.7 & 3.5 & 3.9 & 4.1 \\
Construction & 5.0 & 5.2 & 3.5 & 4.4 & 3.3 & 3.3 \\
Wholesale and retail trade, & 13.1 & 13.1 & 13.2 & 15.2 & 14.8 & 14.9 \\
$\quad$ & & & & & & \\
$\quad$ hotels and restaurants & 5.9 & 6.6 & 6.7 & 7.4 & 8.0 & 8.6 \\
$\quad$ communication & & & & & & \\
Finance, insurance, real & 7.7 & 8.3 & 8.2 & 10.4 & 12.7 & 15.1 \\
$\quad$ estate and business services & & & & & & \\
Other services & 7.3 & 7.2 & 7.2 & 7.7 & 7.6 & 8.2 \\
Government services & 9.6 & 11.4 & 8.8 & 7.1 & 6.8 & 7.2 \\
$\quad$ Less Imputed bank service charges & 2.3 & 3.8 & 4.4 & 5.3 & 7.5 & 9.6 \\
$\quad$ Plus Import duties & 5.2 & 4.4 & 3.7 & 4.1 & 2.2 & 2.4
\end{tabular}


Table 2. Indicator of Manufacturing Performance: $1982-2002$

\begin{tabular}{|c|c|c|c|c|c|c|c|}
\hline Year & $\begin{array}{l}\text { Value of real } \\
\text { output } \\
\text { (RM Million) }\end{array}$ & $\begin{array}{l}\text { Annual } \\
\text { growth rate of } \\
\text { output }(\%)\end{array}$ & $\begin{array}{l}\text { Value of real } \\
\text { output as \% } \\
\text { GDP }\end{array}$ & $\begin{array}{l}\text { Export of Mfg } \\
\text { goods } \\
\text { (RM Million) }\end{array}$ & $\begin{array}{l}\text { Export of Mfg goods } \\
\text { as } \% \text { of total } \\
\text { Export. }\end{array}$ & $\begin{array}{l}\text { Annual } \\
\text { Rate of } \mathrm{Mfg} \text {. } \\
\text { Exports ( \% ) }\end{array}$ & Growth \\
\hline 1982 & 30,943 & & 49 & $7,950.5$ & 28.3 & & \\
\hline 1983 & 32,942 & 6.5 & 47 & $9,883.80$ & 30.2 & 22.9 & \\
\hline 1984 & 35,016 & 6.3 & 44 & $11,510.40$ & 29.8 & 15.9 & \\
\hline 1985 & 35,670 & 1.9 & 46 & $11,973.20$ & 31.5 & 3.8 & \\
\hline 1986 & 36,262 & 1.7 & 51 & $13,991.90$ & 39.2 & 25.3 & \\
\hline 1987 & 41,354 & 14.0 & 51 & $18,765.00$ & 41.5 & 31.3 & \\
\hline 1988 & 48,983 & 18.4 & 53 & $25,303.50$ & 45.8 & 28.4 & \\
\hline 1989 & 58,510 & 19.4 & 56 & $34,536.00$ & 51.1 & 28.6 & \\
\hline 1990 & 69,230 & 18.3 & 58 & $44,018.60$ & 55.3 & 28.6 & \\
\hline 1991 & 83,021 & 19.9 & 61 & $58,212.10$ & 61.6 & 29.8 & \\
\hline 1992 & 90,888 & 9.5 & 60 & $67,869.10$ & 65.5 & 15.7 & \\
\hline 1993 & 104,475 & 14.9 & 61 & $85,559.80$ & 70.6 & 23.6 & \\
\hline 1994 & 122,993 & 17.7 & 63 & $114,797.40$ & 74.6 & 31.9 & \\
\hline 1995 & 153,846 & 25.1 & 69 & $140,095.70$ & 75.7 & 18.5 & \\
\hline 1996 & 277,885 & 80.6 & 110 & $151,189.50$ & 76.7 & 5.9 & \\
\hline 1997 & 296,241 & 6.6 & 105 & $171,058.30$ & 77.4 & 12.4 & \\
\hline 1998 & na & na & na & $228,428.50$ & 79.7 & 28.5 & \\
\hline 1999 & 342,549 & na & 114 & $260,855.70$ & 81.1 & 14.3 & \\
\hline 2000 & 412,763 & 20.5 & 120 & $303,359.80$ & 81.3 & 15.8 & \\
\hline
\end{tabular}

Source: Malaysia Economic Statistic-Time Series 2002, Department of Statistic(2003)

Table 3. Definition of each sector under food and beverages

\begin{tabular}{|l|l|}
\hline Sector & Classification \\
\hline $151(\mathrm{~V} 1)$ & Production, processing \& preservation of meat, fish, fruits, vegetables, oils and fats. \\
\hline $152(\mathrm{~V} 2)$ & Manufacture of diary products \\
\hline $153(\mathrm{~V} 3)$ & Manufacture of grain mill products, starches and starch products and prepared animal feeds. \\
\hline $154(\mathrm{~V} 4)$ & Manufacture of bakery products. \\
\hline $155(\mathrm{~V} 5)$ & Manufacture of beverages \\
\hline
\end{tabular}

Note: ( ) denote definition that we are going to use now on for each sector.

Table 4. The Unit Root Test for Non-Stationarity

\begin{tabular}{lllll}
\hline \multirow{2}{*}{ Variables } & Level & \multicolumn{3}{l}{ irst Difference } \\
\cline { 2 - 5 } & Constant & Constant & Constant no Trend & Constant with Trend \\
\hline No Trend & With Trend & $-6.0514 * * *$ & $-6.1424 * * *$ \\
$\mathrm{~N}$ & -1.1707 & -3.3131 & $-5.2158^{* * *}$ & $-5.0372 * * *$ \\
$\mathrm{X}$ & -0.15072 & -3.2148 & $-6.5312^{* * *}$ & $-6.4422^{* * *}$ \\
$\mathrm{~S}$ & $-0.41527^{* *}$ & -2.6207 & $-3.5328^{* *}$ & -3.5093 \\
V1 & -0.41840 & -2.2923 & $-3.3987^{* * *}$ & $-3.8207 * * *$ \\
V2 & $-5.8308^{* *}$ & $-5.9843^{* *}$ & $-3.9428^{* * *}$ & $-5.4114^{* * *}$ \\
V3 & $-3.4845^{* *}$ & -2.0595 & -2.8116 & $-2.7288^{* *}$ \\
V4 & -1.4429 & -2.4755 & $-6.0478^{* * *}$ & $-6.5966^{* * *}$ \\
V5 & -0.9336 & -1.6485 & -2.5664 & -3.3578 \\
\hline Note: & -2.8990 & -1.1688 & &
\end{tabular}

The null hypothesis is that the series is non-stationary, or contains a unit root. The rejection of null 
hypothesis for ADF test is based on the MacKinnon Critical Values

** indicates the rejection of the null hypothesis at $5 \%$ significance level.

$* * *$ indicates the rejection of the null hypothesis at $1 \%$ significance level

Table 5. Test for Cointegration Relationship

\begin{tabular}{llllll} 
& F-statistic & & & \\
\hline \hline 3 digit MSIC 2000 & V1 & V2 & V3 & V4 & V5 \\
F $\Delta$ V/ $(\Delta \mathrm{V}, \mathrm{Y}, \mathrm{X}, \mathrm{N}, \mathrm{S})$ & $5.1709^{* * *}$ & $3.6797^{*}$ & $5.6947^{* * *}$ & $3.749^{*}$ & $3.4606^{*}$ \\
$\mathrm{~F} \Delta \mathrm{Y} /(\Delta \mathrm{Y}, \mathrm{V}, \mathrm{X}, \mathrm{N}, \mathrm{S})$ & 2.0504 & 1.9811 & 2.4806 & 1.8058 & 2.0949 \\
$\mathrm{~F} \Delta \mathrm{X} /(\Delta \mathrm{X}, \mathrm{V}, \mathrm{Y}, \mathrm{N}, \mathrm{S})$ & 0.9093 & 0.9874 & 1.4585 & 0.7403 & 2.2818 \\
$\mathrm{~F} \Delta \mathrm{N} /(\Delta \mathrm{N}, \mathrm{V}, \mathrm{Y}, \mathrm{N}, \mathrm{S})$ & 1.2704 & 1.0786 & 1.0789 & 1.0163 & 0.9493 \\
$\mathrm{~F} \Delta \mathrm{S} /(\Delta \mathrm{S}, \mathrm{V}, \mathrm{Y}, \mathrm{X}, \mathrm{N})$ & 1.7585 & 1.5937 & 0.92 & 1.8852 & 2.1294
\end{tabular}

Notes: The relevant criteria value bounds are given in Table C1(iii): unrestricted intercept and no trend; number of regressors $=5$ (Pesaran et.al. 2001). The critical values are $2.26-3.35$ at the $90 \%$ significance level, $2.52-3.79$ at the $95 \%$ significance level and 3.41-4.68at $99 \%$ significance level. Asterik *,**,*** denote that F-statistics falls above the $10 \%, 5 \%, 1 \%$ upper bound, respectively.

Table 6. Diagnostic Testing for ECM model ${ }^{*}$

\begin{tabular}{llllll}
\hline Variables & Serial correlation & RESET (1) & NORM (2) & HET (1) & Adjusted-R $^{2}$ \\
\hline V1 & 2.33 & 0.25 & 2.77 & 0.17 & 0.98 \\
V2 & $(0.13)$ & $(0.77)$ & $(0.25)$ & $(0.67)$ & \\
& 0.61 & 1.04 & 3.12 & 2.52 & 0.97 \\
V3 & $(0.44)$ & $(0.18)$ & $(0.21)$ & $(0.11)$ & \\
& 1.02 & 1.41 & 0.94 & 2.15 & 0.99 \\
V4 & $(0.19)$ & $(0.24)$ & $(0.63)$ & $(0.14)$ & \\
& 0.01 & 0.51 & 0.55 & 2.65 & 0.99 \\
V5 & $(0.94)$ & $(0.68)$ & $(0.56)$ & $(0.10)$ & \\
& 0.21 & 0.88 & 1.34 & 1.52 & 0.99 \\
\hline
\end{tabular}

Note: the figures in ( ) indicate the p-value. Asterisk *, $* *$ and $* * *$ denote significant at $10 \%, 5 \%$ and $1 \%$ critical level, respectively.

* ECM model:

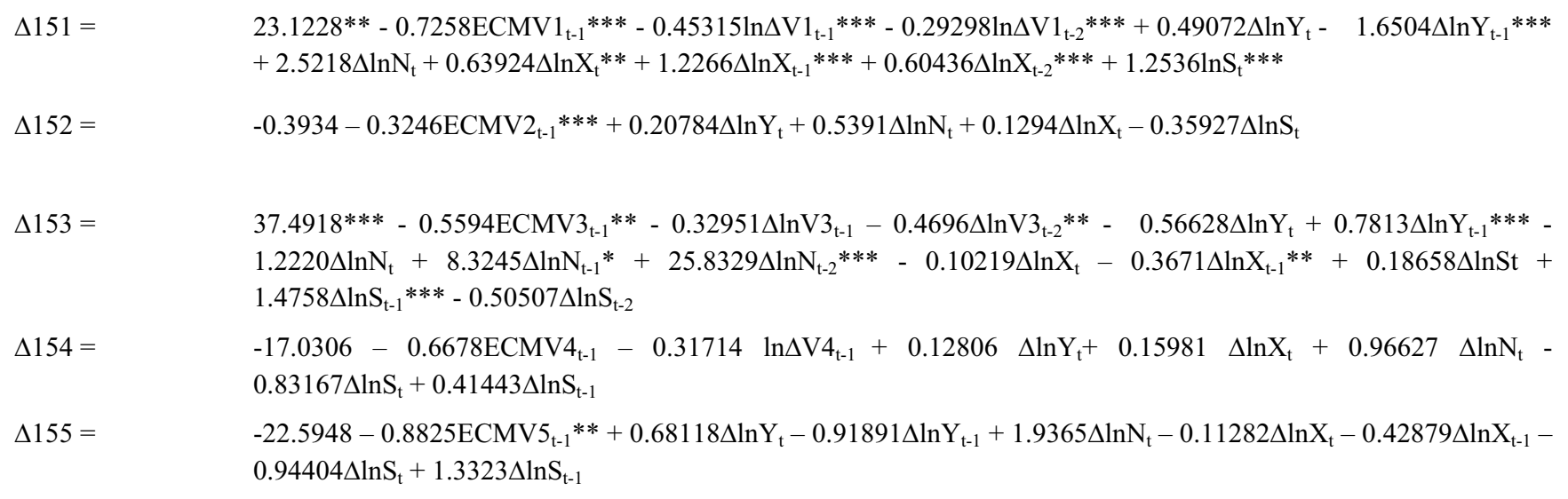


Table 7. Estimated Long Run Coefficients using the ARDL Approach

\begin{tabular}{llllll}
\hline & INPT & YLOG & NLOG & SL0G & XL0G \\
\hline \multirow{2}{*}{ V1 } & $50.0505^{* *}$ & $4.2863^{* *}$ & $10.5645^{* * *}$ & $2.6084^{* * *}$ & 0.2122 \\
& $(2.4637)$ & $(2.5011)$ & $(-4.8317)$ & $(5.0374)$ & $(.28545)$ \\
V2 & 25.7474 & -0.5067 & -2.0033 & -0.1814 & 1.1322 \\
& $(1.1367)$ & $(-0.23913)$ & $(-0.59221)$ & $(-0.22023)$ & $(1.7619)$ \\
V3 & $9.1069 * * *$ & $0.5340^{* *}$ & $-0.5418^{* *}$ & $-0.2344 * *$ & $0.6657^{* * *}$ \\
& $(7.0430)$ & $(3.1265)$ & $(-3.0643)$ & $(-3.1612)$ & $(13.3126)$ \\
V4 & -110.0354 & 3.5529 & 19.9100 & -8.5483 & -0.7242 \\
& $(-1.3803)$ & $(0.8881)$ & $(1.5165)$ & $(-1.3810)$ & $(-0.5417)$ \\
V5 & $-73.7671 * * *$ & $1.9030 * * *$ & $12.7825 * * *$ & $-4.2032 * * *$ & $0.6564 * *$ \\
& $(-23.5108)$ & $(12.8349)$ & $(29.7211)$ & $(-38.9880)$ & $(-8.40561)$ \\
\hline
\end{tabular}

Note: $\mathrm{t}$-values given in ( )

*,** and *** indicate significant at $0.1,0.05$ and 0.01 marginal value

INPT represents the intercept term, Y (per capita income), N (population),

$\mathrm{X}$ (export), S (skill) 
Appendix 1: Detailed description of item under three digit classification

151 Manufacture of vegetable and animal oils and fats

$151115111(31110 \mathrm{p})$ Processing and preserving of poultry products

1512 15120(31140) Processing and preserving of fish and fish products

1513 15131(31131) Pineapple canning

15139(31139) Canning and preserving of other fruits and vegetables

1514 15141(31151) Manufacture of coconut oil

15142(31152p) Manufacture of crude palm oil

15143(31152p) Manufacture of refined palm oil

15144(31153) Manufacture of palm kernel oil

152 Manufacture of diary products

1520 15201(31121) Manufacture of ice cream

$15202(31129$ p) Manufacture of condensed, powdered and evaporated milk

15209(31129p) Manufacture of other dairy products

153 Manufacture of grain mill products, starches and starch products, and prepared animal feeds

1531 15311(31161,31162) Rice milling

15312 (31163) Flour miling

15319 (31169) Manufacture of flour/grain mill products

1532 15321(31216) Manufacture of starch

15322(31219) Manufacture of glucose and glucose syrup maltose

15323(31164) Manufacture of sago and topioca flour/ products

15329(31159p,31219p) Manufacture of other starch products

154 Manufacture of bakery products

154115411 (31171p) Manufacture of biscuits and cookies

15412 (31172) Manufacture of bread, cake and other bakery products

1542 15420(31180) Manufacture of sugar

154315431 (31190p) Manufacture of cocoa products

15432 (31190p) Manufacture of chocolate products and sugar confectionary

154415440 (31214) Manufacture of macaroni,noodles and similar products

15491 (31211) Manufacture of ice

15492 (31212) Manufacture of coffee

15493 (31213) Manufacture of tea

15494 (31215) Manufacture of spices and curry powder

15495(31190p) Manufacture of nut and nut product

$15496(31119 \mathrm{p})$ Manufacture of sauces including flavouring extracts such as monosodium glumate

15497 (31219p,31171p) Manufacture of snack: cracker/ chips (e.g prawn/fish crackers(keropok),potato/ banana/ topioca chips)

15499(31219p) Manufacture of other food products

155 Manufacture of beverages

15530(31330) Manufacture of malt liquors and malt

15541(31340p) Manufacture of soft drinks

15542(31340p) Production of mineral products

Note: ( ) code under M.I.C. 1972 